\title{
Characteristics of English Teachers when Training Global Multi Cultural Students (Sinop Sample)
}

\author{
Hakan UŞAKLI \\ Sinop Universitesi Egitim Fakultesi \\ E-mail: husakli@sinop.edu.tr
}

\begin{abstract}
Language teaching, particularly English language teaching was discussed in this study. That is why it is integral to the globalization. The study demonstrates that problems addressed from the aspects of administration, educational program and psychology can indeed be generalized to all.

This study is conducted according to qualitative research methods. 60 English teachers explained their ideas on qualifications and teaching standards. As a conclusion, it was emphasized that English learning is a life style rather than simply being a preparation for passing examination. It is recommended for researchers to study on possible problems of multicultural education and their way of solutions.
\end{abstract}

Keywords: Small cities, Globalization, Foreign language teaching, Multi cultural student

\section{Introduction}

"I feel like they understand me wrongly?" "I mean that the Great not the God" "Mr. Hakan please help us!" "O Sir I said five multiply five! not multi fifth!" These are perhaps funny for you but it is the shame of us. Although we are educators and multicultural counselors or only guidance practitioners, perfect pronunciation of English is something like these and we force our pupils to understand us whatever their reaction is that. Is this fair or unfair? These dilemmas shorten our creativity to teach the students any piece of knowledge or overcome our personal problems. As one of client stated that “... that foreign scholar doesn't have any right to force me to solve all nonsense social problem. That's why the outside life is different. All my friends who don't have any diploma have much better life than me." This statement reflects the reality picture of student's when they met any foreign teacher.

Language is an unquestionable prerequisite for human communication (Sasaki, Suzuki and Yoneda, 2006). English is integral to the globalization processes. It has stress in international politics and economic issues. The crucial role of English is that it has privileged role being wide worth structures such as the United Nations, the World Trade Organization, and regional groupings such as North American Free Trade Agreement and the European Union (Phillipson, 2001, p. 187). If we can both learn from and teach others across borders then the opportunities for reading and writing across cultures can, in the words of Fox (2007), help us to "transform languages of harm into literacies of hope."

Teaching and learning English is also valuable for concerned. Used as we have become to the rhythms of British or American voices echoing through our environments announcing that English belongs to the world. Without questioning the veracity of both descriptions, indeed precisely for this reason, this paper argues for a critical pedagogy of English as a Global Language (Guilherme, 2007, p. 72). The global enterprise of English language teaching (ELT) ought to present the possibility of bringing millions of people into the global traffic of meaning.

We face too many problems in teaching English not only with elementary age children but also with adults. Choosing suitable method teaching English is crucial. There are methods using widely such as: grammar-translation, audio-lingual, cognitive-code, natural, communicative approach and eclectic methods (Demirel, 2004a: 29).

However, quite often teacher trainers turn out to be people who could manipulate some certain classroom techniques. This is why it has been suggested above that every language teacher should know at least a bit of applied linguistics himself (Demirel, 2004b: 5).

Although elementary age students eagerly too learn foreign language with the $94 \%$ some handicaps make it difficult to teaching such as lecture books, techniques, methods, classroom physical conditions (Mirci, 2001: 7-8).

Teachers should take into account some wide perspective as a professional (Krowits, 1985). A variety of tested techniques is included for stimulating conversation among students with a basic command of English. "The Art of Conversation," contains observations on conversation among native English speakers, a discussion of language styles, and comments on the importance of listening. Subsequent chapters deal with specific techniques or devices for stimulating conversation, such as questions and answers, dialogues, plays, speeches, audio and visual aids, television and movies, field trips and games (Dobson, 1987). 
There are some teaching standards and strategies. The key to learning in such a project lies in the reflection the students engage in after they have been online with students from other countries. Rhedding-Jones (2002) states that specifically; it would request that local differences be recognized by teachers and examiners as concrete manifestations of new forms of globalization or glocalization. In these ways, students and teachers would act more as agents of globalization than as its objects.

Globalization has been defined as the intensification of worldwide social relations which link distant localities in such a way that local happenings are shaped by events occurring many miles away and vice versa. For language teachers around the world, the question is how discussions about globalization taking place in sociological circles relate to their overall approach to language teaching, and to their day-to-day practice. Until quite recently, a hyperglobalist position dominated discussions regarding the spread of English as a benign outcome of globalizing forces (Block, 2004).

Global age or world is the key concept of present time educators. How can we teach our students the importance of global issues? It can be better to find suitable model. This situation was explained comprehensively in Nihalani's (2008) research abstract: Communication is one of the keywords of the global age. The ever-increasing use of English as a World language has clearly meant that British RP and American Standard English (GA) are no longer seen as the models that learners aspire to. With the global spread of English, three major related questions come to our mind: (a) diversity and multicultural identity, (b) mutually intelligible international communication, and lastly (c) the pedagogical issue of an educational target for global communication. After a critical examination of the impact of globalization on the educational patterns in general and English language teaching in particular, this paper focuses on the intercultural communication in the global context, and examines the three much-debated major related issues of 'comprehensibility', 'intelligibility' and 'interpretability' from the perspectives of linguistics and social psychology. Quantitative acoustic data from the Expanding Circle (Japanese English), the Outer Circle (Indian English, Malaysian English, Singapore English, Brunei English, Nigerian English, etc.), and the Inner Circle (British English, Scottish English and American English) will be presented. In conclusion, a pragmatic model that is informed by the multi-dimensional view of intelligibility and, more importantly, multicultural interpretability will be discussed in order to address the third major concern of language standardization for global communication.

For the global age, teachers and students should bear in their mind that there are standards. Nault (2006) stated the manner in which culture is taught to English learners needs to be rethought in light of the globalization of the English language. It is maintained that change is needed in at least in three areas. First, English teaching professionals should discard the notion that the US and Great Britain represent the sole 'target cultures' of the English language. Second, they should rethink the goals of culture and language education to meet their students' diverse needs well. And third, ELT professionals should do more to design and/or select teaching materials that are international and inclusive in scope. As a conclusion, English instructors should educate themselves well and their students on world cultures to promote genuine linguistic/cultural awareness and international understanding.

There are many individuals, globally and locally, who are working to make English more equitable purposes, which means that we have cause for feeling confident in addressing the major challenges that we face professionally (Phillipson, 2001, p. 197).

The aim of this study is to find out what the teachers think about how multi cultural teachers reflect their way of life. As a small city, Sinop, Turkey has the foreign language teaching problem and needs cross cultural consultation. In a rapidly changing world, we live in an age of information boom, in which the teaching of language is bound to play a key role in the future of societies. Multi culturality, bilingualism or multi lingualtiy are basic terms that we should be aware of. Importance of this study is hidden in the globalization of world in general. As a candidate country to the European Union, do we think we are ready to Europe multi cultural features?

This study is limited with only English teacher. There are a few German and French courses in some schools in Turkey. The study also limited teachers-students interaction in schools.

Sinop as a small city: Sinop located on Boztepe Hill and it is a peninsula which is located on the most northern edge of the Turkish side of Black Sea coast. In the past it is known as Paphlagonia region, in modern-day northern Turkey. It is historically known as Sinope. It is the capital of Sinop province. Sinop is also famous for great philosopher Diogenes. Sinop has also clean sea and delicious fish and natural beauties which attract tourists a lot. Thus gives a chance for the students to meet the foreigners in Sinop.

Number of people living in Sinop when it is compared to Istanbul where 12.569.041 people live is 101.383 (Tuik, 2008). Due to the low population density and being away from big cites such as Ankara, Istanbul and Izmir, Sinop is one of the underdeveloped city of Turkey. Sinop is one of the mid Black Sea cities which has only one university with Education, Science and art, Fisheries Faculties, Vocational and Health Schools, this attracts the foreigners. 
When we compare to any European city such as Graz in Austria, there is a lot of differences, and once in awhile things are seen from a different angle (Garz, 2007, p. 20). With its four universities, the universities of applied science and the private research institutions, the culture capital Graz not only has a wealth of art but also is up front when it comes to new developments and technical progress. These characteristics of Graz attract mobile students (Schrettle, 2007).

At the individual level, the reason of choosing to study abroad is to find to reflect arrangement of decision making influences. For example, in one of the study of student mobility in the EU identified the wish to enhance foreign language student choices: moreover, many students stated that it had always been their wish to study abroad.

Inferior and, language agreement is more crucial for mobile students in any part of the word. In this vain we can see importance of English. Teaching English is very important that's why students need intermediate English to communicate with students who are visiting. Moreover these students need advanced level of English to be mobile.

Language Teaching:

Language teaching is a field where fads and heroes have come and gone in a manner fairly consistent with the kinds of changes that occur in youth culture. As opposed to physics or chemistry, where progress is more or less steady until a major discovery causes a radical theoretical revision (Kuhn, 1970). The studies of pioneer educators in English teaching such as Celce-Murcia (1991) focus on choosing correct approach. One reason for the frequent changes that have been taking place until recently is the fact that very few language teachers have even the vaguest sense of history about their profession and are unclear concerning the historical bases of the many methodological options they currently have at their disposal (Celce-Murcia, 1991, p. 3). Like in English in any living language, there are skills which teachers should bear in their mind. These are listening, speaking, reading, writing and grammar and vocabulary. In addition to these basic skills of language teaching, there are approaches from 20th century approaches which researchers still give attention (Yilmaz, 2004). These approaches are grammar-translation, direct, reading, audiolingualism (mainly in U.S.), situational (in British), cognitive, affective-humanistic, comprehension and communicative.

Menges (1994), states that improving teaching English were crucial for teachers they should bear in mind that motivation student their course and for life long learning (P. 349)

Yilmaz (2004) focused on communicative approach and need assessment of Turkish university students.

A reaction to the behaviorist features of the audio-lingual approach; there are seven elements in cognitive approach:

a. Language learning is viewed as rule acquisition, not habit formation.

b. Instruction is often individualize; learners are responsible for their own learning.

c. Grammar must be taught but it can be taught deductively (rules first, practice later) and/or inductively (rules can either be stated after practice or left as implicit information for the learners to process on their own).

d. Pronunciation is de-emphasized; perfection is viewed as unrealistic.

e. Reading and writing are once again as important as listening and speaking.

f. Vocabulary instruction is important, especially at intermediate and advanced levels.

g. Errors are viewed as inevitable, something that should be used constructively in the learning process.

$\mathrm{h}$. The teacher is expected to have good general as well as an ability to analyze the target language (Celce-Murcia, 1991, p. 7).

Communicative approach is useful for teaching English in multi cultural settings Larsen-Freeman (1986 123). Globalization, relation with EU (European Union) and student mobility increase importance of learning and teaching English.

\section{Method}

Research Approach:

Technique of qualitative research is used in this study. Qualitative researches depend on meanings, definitions and experiences of data. Data will consist of mostly words which people define and observe (Coolican, 1992). In the sample of the research 60 English teachers were included who worked in Sinop in the academic year of 2009-2010. Qualitative researches are preferable for their depicting or illustrating a case as it is features. (Karasar, 2002, p. 77). A semi-constructed questionnaire form developed by the researcher to establish the techniques used by English teachers for foreign language teaching problem and cross-cultural consultation was used as a tool of data collection in this study. In the first step of developing the questionnaire, a trial form was prepared through literature scanning. 
The questionnaire was given the final form in parallel with the ideas and criticism directed by experts to the trial form. Content analysis is one of the most commonly used methods for analyzing qualitative data (Twycross \& Shields, 2008, p.38). The data obtained from semi-constructed interview questions in qualitative research were summed up through content analyses. In order for the validity of the data subjected to content analyses to be calculated, the same text should be coded in two different times with a certain number of data taken from among the data obtained. In this process, it is important to know whether or not the same word, statement or paragraph is coded in the same category. A compliance or consistency level of $80 \%$ between the categories is accepted to be satisfactory for reliability. In this research, it can be stated that a compliance percentage of $86 \%$ shows the content analyses made is reliable enough. After the data were coded, they were gathered under main themes and in the presentation of the data, frequency was used. Afterwards, comments were made in accordance with the frequencies. In the analysis of the data collected, frequency ( $\mathrm{f}$ ) analysis is to be made and the results obtained are to be presented in tables. Percentages of statements were given Table I illustrates teachers' perception on training students for multicultural settings.

In globalization world, number of studies has been conducted in order to establish the multi language teaching techniques in terms of the objectives previously determined. The case isn't the same in our country, so the efficiency or productivity of languages techniques should be questioned in order for the needs have to be answered. Not many languages it seems that we only need for teaching English more seriously. Such research is thought to fill in a significant gap in the literature concerned. It is expected that the data to be obtained will not only help teachers to review their knowledge difficulties of English teaching but also to provide assistance for those doing cross cultural concentration. In addition, this research is thought to initiate opportunities for new research, discussions, and thinking about the importance of multi culturally.

In order to reach the goals previously stated, answers to the following questions ought to be inquired:

1. What do you think about multi cultural features of English teachers with regards to globalization?

2. Do you have any special approach or technique for this era?

3. Do you think that you have potent for educating mobile students?

4. Do you believe that your students can get rid of difficulties when they mobile any part of world?

1 Multi cultural features of English teachers

All the teachers involve in interviewed believe that they have multi cultural competency. They think that they can help any mobile student incoming or outgoing.

(M. 39) It doesn't matter for me. I can help any student even older scholar who wants to visit Sinop or go any place abroad. I believe that I am multicultural potent. Every day, I follow news not only about Turkey but also world wide. Teaching especially English teaching is a child game for me.

2 Approach or technique

Only $\% 45$ of teacher responds that they can reflect the way of their own life when they are teaching. Administration limiting is their reflection $76 \%$. Programs should be changed $86 \%$. Programs should involve multi cultural samples $63 \%$

(F 30). I want to be model for my student not only with academic way, but also with my ideas about politics, life style. I know I don't have right. Rules are limiting us. I wish I would ware my colorful pants, T shorts.

3 Potent for educating mobile students

Teachers stated that they have lack of language teaching approach. They only stress on the strategies of cognitive approach. Table I shows approaches and technique that teachers mostly apply

(M 32) What I really do is only to teach grammatical rules, reading and pronunciation.

4 Difficulties faced

All teachers stated five and more item that they face difficulties when teaching English. Mostly they complain about programs, administration and motivation

5 Students overcome difficulties when they are mobile

All teachers had tendency that they didn't experienced or needed such a kind of cultural awareness.

Teachers have positive attitudes toward students (92\%). The limited time with new programs shortened the time that teacher and student togetherness. Approximately only two hours average of a week seems not enough to establish and maintain constructive relation with students 
(F 44) I like my students. But English lesson time is too short. Only two hours in a week, I can see the class. This time I only give my course. I don't think that today student can over come troubles when they are abroad. They need extra study for English. So it is too difficult when they visit in any country. But we can overcome this problem.

(M 56) I remember that about 20 years ago, we have fewer students but more lesson time. I taught English songs to my students. Some of my students had pen friends. Although computer and also internet was available for every body, I don't think that students have foreign friends whom they connect with e mails. If they had, I would have known.

\section{Conclusion, Discussion and Recommendations}

Sinop is one of the smallest cities in Turkey. Although it has natural beauty, there are some limits in economical development. In this study, English language teachers' ideas on multi culturality and their competence on teaching and limitations of teaching investigated. The study group which consists of 60 English teachers as full and part time was interviewed with semi structured 5 questions. With the help of content analyses, teachers ideas on

The study was executed with English teachers in Sinop to gather information on their number, educational level and knowledge and skills in foreign language teaching. Results of the study indicate that in elementary and secondary schools, teachers have lack of original skills and strategies for teaching English, whereas in higher education, English teaching doesn't have an image of an occupation on its own due to the insufficient command-duty consciousness. Although crowded classrooms, uninterested students, insensitive administrators are identified as common complaints of the teachers, teachers recommend the students should develop shallow solution models for these problems such as language laboratory, material room and resource adequacy. Teachers think that they are ready take part in globalization. As Phillipson (2001) indicates the importance of English for global world, teachers are also aware of this importance. In globalization prepare communication is golden skill for any mobile student. As Celce-Murcia (1991) points out the features of communicative approaches of seven points, this is also important for 21 st teachers to prepare their students. But this is not enough for multi cultural settings.

Teachers think that they have potent for incoming students. But it is not easy to give education for mobile students. Teachers think that they should get information about new teaching strategies.

According to the teachers, their students need more extra curricular activities for becoming mobile students. Their standards are not equal with their Europe counterparts. More lectures, seminars or such kind of activities should be edited especially information cultural for students.

As method, qualitative research techniques such as interview, observation were used. 60 people including full time and part time English teachers were included as a study group.

It is imperative that in small cities like Sinop, where the population density is low, solution projects based on instructional method of repetition under the supervision of individuals whose occupational studies must be accepted by all institutions and be developed. Language teaching particularly foreign language teaching ought to be executed by professionals. There are problems limiting us when teaching English language. These problems and considering their relation with the educational program and administration were examined in the study. Apart form this general framework, teacher qualities for training or preparing students multi culturally were mentioned in this study. Teaching and learning English is crucial. Specification in any approaches must be familiar with western life, motivation, persuasiveness, program arrangement, maintenance good relation with administration and other teachers are the words that teachers frequently use. This is correct conclusion as Menges (1994) indications.

As Demirel (2004a; 2004b) states choosing suitable methods is very important. Classroom physical conditions and course program features make some trouble in teaching English with children (Mirci, 2001). Structured good conversation groups makes for teachers to teach English (Dobson, 1987). As a professionals Teachers should give attention to perspective (Krowits, 1985).

As a conclusion, it is stated that we have to re arrange our educational settings. Perhaps more lingual lectures, guidance seminars and different teaching approaches, lectures can have positive effect for more mobile scholars and students.

\section{References}

Block, D. (2004). Globalization and language teaching. ELT Journal: English Language Teachers Journal; 58 (1) 75-77.

Celce-Murcia, M. (1991). Language Teaching Approaches: An Overview. In. M. Celce-Murcia (Ed.), In teaching English as a second or foreign language (pp. 3-10). Boston: Heinle \& Hinle Publishers.

Coolican, H. (1992). Research methods and statistics in psychology. London: Hodder \& Stougtton. 
Demirel, O. (2004a). ELT Methodology. (3 ${ }^{\text {rd }}$ Edt.) Ankara: pegam A Publication.

Demirel, O. (2004b). Yabanci Dil Ogretimi Dil Pasaportu Dil Biyografisi Dil Dosyası (2 Baski). Ankara: pegem A Yayincilik.

Dobson, J. M. (1987). Effective Techniques for English Conversation Groups. Washington D.C.: English Language Programs Division.

Fox, F. R. (2007). Literacies of harm and hope. Paper presented at the China-U.S. Conference on Literacy, Beijing, China.

Graz, (2007). Graz 2007 How about a new passion? Wien: Conception and design.

Guilherme, M. (2007). English as a Global Language and Education for Cosmopolitan Citizenship. Language \& Intercultural Communication; 7 (1) 72-90.

Turkiye Istatistik Kurumu Nufus Sayım 2007 Turkiye genel Retreved from http://report.tuik.gov.tr/reports

Karasar, N. (2002). Bilimsel Araşttrma Yöntemi: Kavramlar, Ilkeler, Teknikler [Scientific methods of research: Concepts, principals, techniques]. Ankara: 3A Araştırma Eğitim Danışmanlık Ltd

Krowits, M. J. (1985). English for Professionals: A teacher's Perspective. Washington D.C.: English Language Programs Division.

Kuhn, T.S. (1970). The Structure of Scientific Revolutions. Chicago: University of Chicago Press.

Menges, R. R. (1994). "Motivating students for your course and for lifelong learning” Teaching Tips (Edit: Wilbert J. McKeachie) ninth edition, Canada D.C. Heath \& Company

Nault, D. (2006). Going Global: Rethinking Culture Teaching in ELT Contexts. Source:Language, Culture \& Curriculum 19 (3) p314-328.

Mirci, İ. H. (2001). Cocuklara Yabanci Dil Ogretimi. Ankara: gazi kitapevi.

Nihalani, P. (2008). Globalization and Multicultural Communication: Unity in Diversity. RELC Journal 39 (2) p242-261.

Phillipson, R. (2001). English for Globalisation or for the World's People? International Review of Education 47 (3-4). 185-200.

Rhedding-Jones, J. J. (2002). English elsewhere: glocalization, assessment and ethics. Journal of Curriculum Studies 34 (4) p383-404.

Sasaki, M.; Suzuki, T. \& Yoneda, M. (2006). English as an International Language in Non- Native Settings in an Era of Globalization. Comparative Sociology 5 (4) p381-404.

Schrettle, A. (2007). Academic culture Pad. Zentrum der Diozese Graz-Seckau, Europe Compact IV. Graz: Copy Material.

Twycross, A.; Shields, L. (2008). Content analysis. Paediatric Nursing 20 (6) p. 38.

Yilmaz, C. (2004). A Needs analysis of teacher trainees in the English departments of Turkish universities within the framework of communicative language teaching Unpublished Doctoral Dissertation. Dokuz Eylul University, Izmir Turkey. 
Table 1. Opinions of English Teachers Training Global Multi Cultural Students

\begin{tabular}{|c|c|c|c|c|}
\hline 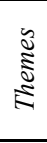 & Categories & $\begin{array}{l}\text { Number of } \\
\text { teacher agree } \\
\text { category } \\
\text { (n:60) }\end{array}$ & $\begin{array}{l}\% \\
\text { participants } \\
\text { category }\end{array}$ & Examples Teacher Opinions \\
\hline \multirow{9}{*}{ 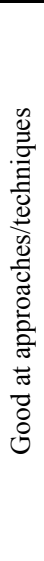 } & Learning rules & 58 & 97 & English language is construction of rules. (T21) \\
\hline & $\begin{array}{l}\text { Individualized } \\
\text { instruction }\end{array}$ & 32 & 53 & Same students could need extra help (T10) \\
\hline & Correct pronunciat. & 55 & 92 & Any English teacher should properly pronounce fluently (T8)* \\
\hline & Reading & 58 & 97 & $\begin{array}{l}\text { "these are good stories or novels read and read. This is what we } \\
\text { have difference" (T28) }\end{array}$ \\
\hline & Writing & 50 & 83 & $\begin{array}{l}\text { I believe in power of writing. Using correct words. In creative } \\
\text { writing you can show your magic to the students (T30) }\end{array}$ \\
\hline & Listening & 56 & 93 & $\begin{array}{l}\text { In audio lab. Same students bring conservation mp3. Funny that } \\
\text { they want have you understand that conversations (T36) }\end{array}$ \\
\hline & Speaking & 58 & 97 & $\begin{array}{l}\text { Speaking is our handicap. It is high time schools set up } \\
\text { conversations club. }\end{array}$ \\
\hline & $\begin{array}{l}\text { Vocabulary } \\
\text { knowledge }\end{array}$ & 59 & 98 & $\begin{array}{l}\text { Word power is important especially when you meet foreigners. } \\
\text { I am a English teacher it is not good using simple words (T38) }\end{array}$ \\
\hline & Extra language & 10 & 17 & $\begin{array}{l}\text { As foreign language teachers English is not enough for us. We } \\
\text { should know one more (T40) }\end{array}$ \\
\hline \multirow{10}{*}{ 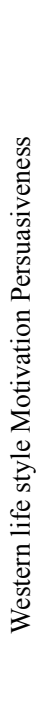 } & $\begin{array}{l}\text { Travel several } \\
\text { European and USA }\end{array}$ & 45 & 45 & $\begin{array}{l}\text { I think government support us to travel. So we can encourage to } \\
\text { students go abroad. (T43) }\end{array}$ \\
\hline & Get use to foods & 25 & 42 & $\begin{array}{l}\text { Any foreign teacher is also cultural ambassador. It is important } \\
\text { to know other cultures food of name of meals. (T44) }\end{array}$ \\
\hline & $\begin{array}{l}\text { Important features } \\
\text { of culture }\end{array}$ & 38 & 63 & $\begin{array}{l}\text { What are the important features of any culture is one of our } \\
\text { concerns. Time square, Hide Park, Eifel Tower (T43) }\end{array}$ \\
\hline & Voice quality & 55 & 92 & $\begin{array}{l}\text { This is diction and good speaking voice that motivate our } \\
\text { students to lessons. (T36) }\end{array}$ \\
\hline & Class arrangement & 58 & 97 & Good teacher is also environmental engineer. (T48) \\
\hline & $\begin{array}{l}\text { Using visual } \\
\text { materials }\end{array}$ & 50 & 83 & $\begin{array}{l}\text { We use to bring class illustration. Okay there are lots of } \\
\text { materials for better teaching as } \mathrm{CD} \text {, or internet. However I } \\
\text { think hanging visual illustration more affective. (T49) }\end{array}$ \\
\hline & Teaching & 52 & 87 & \\
\hline & $\begin{array}{l}\text { importance of } \\
\text { globalization }\end{array}$ & & & $\begin{array}{l}\text { Sometimes I inform students about chancing world politically } \\
\text { or economically. }\end{array}$ \\
\hline & $\begin{array}{l}\text { Talk about } \\
\text { European countries }\end{array}$ & 53 & 88 & $\begin{array}{l}\text { Students urge me to talk about EU. Why the union refuse us. } \\
\text { (T51) }\end{array}$ \\
\hline & $\begin{array}{l}\text { Teaching } \\
\text { importance of } \\
\text { English }\end{array}$ & 58 & 97 & $\begin{array}{l}\text { I give example of my visit to Nederland. Student have to go } \\
\text { school at the age of } 4 \text { and they start to learn several language } \\
\text { early ages. English is their mother language as if. (T40) }\end{array}$ \\
\hline \multirow{6}{*}{ 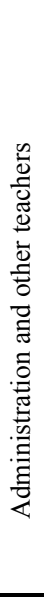 } & $\begin{array}{l}\text { Bringing class } \\
\text { foreigners }\end{array}$ & 35 & 58 & I wish I would call English native speaker my class. (T56) \\
\hline & $\begin{array}{c}\text { Persuade } \\
\text { administration } \\
\text { enroll in EU } \\
\text { education } \\
\text { agreement }\end{array}$ & 32 & 53 & $\begin{array}{l}\text { It is tact of maintain good relation with administration. It is the } \\
\text { administration decision on make something about LLP (T55) }\end{array}$ \\
\hline & $\begin{array}{l}\text { Cooperation with } \\
\text { teachers }\end{array}$ & 39 & 65 & $\begin{array}{l}\text { We should develop our cooperation with other teachers. We } \\
\text { should develop good teaching environments. Extra curricular } \\
\text { activities with the help of other teachers (T55) }\end{array}$ \\
\hline & Develop projects & 32 & 53 & Developing good projects or helping other \\
\hline & $\begin{array}{l}\text { Ready to meetings } \\
\text { upper } \\
\text { administration }\end{array}$ & 28 & 47 & $\begin{array}{l}\text { As a presentable way we get ourselves ready to meetings. We } \\
\text { can only show or open us with upper distraction even minister } \\
\text { of education }\end{array}$ \\
\hline & $\begin{array}{l}\text { Arrange facilities } \\
\text { foreign visits }\end{array}$ & 35 & 58 & $\begin{array}{l}\text { There are lots of natural beauty of Sinop. We should eager to } \\
\text { join meetings with visitors. We can help organization as } \\
\text { translator (T36) }\end{array}$ \\
\hline
\end{tabular}

\footnotetext{
${ }^{*} \mathrm{~T}$ : Teacher and number of teacher
} 